\title{
Limited genetic variability in native buckwheats (Eriogonum: Polygonaceae) on San Clemente Island
}

\author{
Lynn Riley ${ }^{1}, *$, Mitchell E. McGlaughlin ${ }^{2}$, and Kaius Helenurm${ }^{1}$ \\ ${ }^{1}$ Department of Biology, University of South Dakota, Vermillion, SD 57069 \\ ${ }^{2}$ School of Biological Sciences, University of Northern Colorado, Greeley, CO 80639
}

\begin{abstract}
California Channel Island buckwheats are important components of scrub communities on the Channel Islands. A long history of overgrazing by introduced herbivores on San Clemente Island has contributed to scrub vegetation loss and population declines in 2 endemic island taxa, Eriogonum giganteum var. formosum and E. grande var. grande. Since herbivore removal, Eriogonum species, which are early colonizers of disturbed habitats, have been increasing across the island. These increases are thought to facilitate further recovery of the native flora because the shrubs act as nurse plants and improve the soil profile for other native species.

We genotyped individuals from both taxa on San Clemente Island with 6-9 polymorphic microsatellite loci to estimate levels of genetic variability and structure and to detect any genetic impacts that could be attributable to demographic bottlenecks and subsequent early recoveries. Both taxa were characterized by low diversity across the island. Observed heterozygosities ranged from 0.021 to $0.337(\bar{x}=0.188)$, and most populations were fixed for a single allele at several loci. Additionally, Bayesian estimates of inbreeding were high $(0.107-0.477 ; \bar{x}=0.295)$ in most populations. Overall there was little evidence of genetic structure among E. grande var. grande sampling locations; we inferred 1-3 distinct genetic clusters within the taxon, depending on the analysis. In contrast, we inferred consistent genetic differentiation within E. giganteum var. formosum, which generally has lower observed population sizes than E. grande var. grande.

Both E. giganteum var. formosum and E. grande var. grande on San Clemente Island have low neutral genetic diversity compared to other island endemics, suggesting that the introduced herbivores contributed to the genetic effects of severe population bottlenecks and that the long-term viabilities of the taxa may be compromised by low genetic diversities. If this pattern is common among San Clemente Island native shrubs, more active management of the recovering populations may be warranted.
\end{abstract}

REsumen.-El trigo sarraceno es un importante componente de las comunidades de matorrales de las Islas del Canal de California (California Channel Islands). El largo historial de sobrepastoreo de herbívoros introducidos en la isla San Clemente contribuyó a la pérdida de matorrales y a la disminución poblacional de dos taxones endémicos, el Eriogonum giganteum var. formosum y el E. grande var. grande. Desde que se erradicó a los herbívoros, aumentó en toda la isla la presencia de Eriogonum, conocido como los primeros colonizadores de hábitats perturbados. Se cree que dicho aumento podría facilitar la posterior recuperación de la flora nativa ya que los arbustos actúan como plantas nodrizas, optimizando el perfil del suelo para otras especies nativas.

Genotipificamos individuos de ambos taxones de la Isla San Clemente con seis a nueve loci microsatélites polimórficos para estimar los niveles de variabilidad y de estructura genética, y para detectar cualquier impacto genético que pudiera atribuirse a cuellos de botella demográficos y su subsecuente recuperación. Ambos taxones se caracterizaron por baja diversidad en toda la isla. La heterocigosidad observada oscilo entre $0.021-0.337$ (promedio $=0.188$ ) y la mayoría de las poblaciones tuvieron un único alelo fijo en varios loci. Adicionalmente, las inferencias bayesianas de endogamia fueron altas $(0.107-0.477$, promedio $=0.295)$ en la mayoría de las poblaciones. En general, hubo escasa evidencia de estructura genética entre las áreas de muestreo de E. grande var. grande. Inferimos de uno a tres grupos genéticos distintos dentro del taxón, dependiendo del análisis. Por el contrario, inferimos diferenciación genética consistente dentro del E. giganteum var. formosum, que en general, tiene tamaños poblacionales observados más bajos que E. grande var. grande.

Tanto E. giganteum var. formosum como E. grande var. grande de la isla San Clemente presentan diversidad genética neutral baja en comparación a otras islas endémicas, lo que sugiere que los herbívoros introducidos contribuyeron a los efectos genéticos de severos cuellos de botella poblacionales, y que la viabilidad a largo plazo de los taxones puede verse comprometida por la baja diversidad genética. Si este patrón es frecuente entre los arbustos nativos de la Isla San Clemente, podemos garantizar un control más activo de las poblaciones en recuperación.

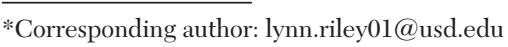


One of the major goals of biological conservation is to preserve the breadth of intrataxonomic diversity and, ideally, the evolutionary potential of organisms under consideration (Bowen and Roman 2005, Jump et al. 2009, Redding and Mooers 2010, Forest et al. 2015). At a broad scale this involves determining the phylogenetic diversity of a region, either within a fauna or flora (Forest et al. 2007, Scherson et al. 2014, Thornhill et al. 2016) or within a lineage (Volkmann et al. 2014, Pollock et al. 2015, Schmidt-Lebuhn et al. 2015), in order to prioritize conserving regions that contribute disproportionately to overall diversity. Protecting such areas may both preserve the evolutionary processes responsible for generating diversity (Forest et al. 2007, Winter et al. 2013) and increase the overall resilience of biological communities, which is positively correlated with genetic and phylogenetic diversity (Reusch et al. 2005, Sgrò et al. 2011, Srivastava et al. 2012). At smaller scales, intraspecific analyses may identify the most genetically diverse and the most genetically unique populations as having high conservation priority (Reed and Frankham 2003, Volkmann et al. 2014) in an effort to retain evolutionary potential.

At regional scales, island systems are natural foci for conservation efforts because they harbor unique biotas and those biotas are uniquely vulnerable (Berglund et al. 2009). Although island faunas and floras are generally depauperate compared to similarly sized mainland areas, members of those faunas and floras are often highly differentiated from their mainland relatives (Kreft et al. 2008). Consequently, about one quarter of all angiosperm species are estimated to be island endemics (Kier et al. 2009). If colonizing populations are small and gene flow from mainland populations is reduced, island populations will quickly diverge from the source population (Whittaker et al. 2008). Additionally, island populations are poorly adapted to human-modified landscapes because successful island colonization is often accompanied by release from selection by mainland predators, competitors, and diseases (Bowen and Van Vuren 1997). Islands are therefore frequently characterized by highly endemic and highly imperiled biotas (Berglund et al. 2009, Kier et al. 2009, Caujapé-Castells et al. 2010).

The California Channel Islands, a group of 8 islands from $20 \mathrm{~km}$ to $100 \mathrm{~km}$ off the west coast of North America in the California Bight, are located within the biologically rich California Floristic Provence (Baldwin 2014). The islands harbor a unique biota, including a highly endemic flora. Although the large islands (San Clemente, Santa Catalina, Santa Cruz, and Santa Rosa Islands) have the richest floras (7-11 native plant communities), even the small islands (Anacapa, San Miguel, San Nicolas, and Santa Barbara Islands with 2-4 native plant communities) harbor several taxa endemic to the islands (Philbrick and Haller 1977, Ratay et al. 2014, Riley and McGlaughlin 2016). Since European settlement in the 19th century, the biota has been highly modified by intentional and accidental introductions (Knowlton et al. 2007). Introduced herbivores decimated many plant populations and denuded the most accessible regions on all of the islands (Rick et al. 2014).

The highest level of floral endemism in the archipelago is found on San Clemente Island where more than $17 \%$ (Moody 2000) of the native taxa are California Channel Island endemics and almost $4 \%$ are endemic to San Clemente alone (Raven 1963). Because San Clemente is the furthest large island from the mainland, both by shortest distance (Moody 2000) and along the most likely aeolian dispersal routes (Riley and McGlaughlin 2016), it may also harbor genetically distinct populations of more broadly distributed taxa. San Clemente Island was used for commercial goat and sheep ranching starting in 1875 (Johnson 1975). Ranching was replaced by naval training exercises as the primary activity starting in 1934, but feral sheep and goat populations remained high. The navy sharply reduced feral animal populations in the 1970s and 1980s and fully removed them by 1991 (Keegan et al. 1994). The navy also undertook restoration efforts to conserve the island's unique biota (Tierra Data Inc. 2013). While we do not have direct measures of the impacts of these activities on the flora of San Clemente Island, the observations of early botanical explorers suggest that the effects were similar to those on other Channel Islands (Raven 1963). For example, Brumbaugh (1980) compared reports from the mid-1800s to present-day aerial photos of vegetative cover on Santa Cruz Island and concluded that sheep, in addition to droughts, denuded much of that island. San Clemente Island also 
supported large numbers of sheep along with thousands of feral goats and is thought to have suffered similar habitat modification and loss of native vegetation (Raven 1963, Johnson 1975).

Since the removal of sheep and goats, native plant populations have expanded dramatically. Several species that were long thought extinct were rediscovered (Wallace et al. 2006, McCune and Knapp 2008, McGlaughlin et al. 2015), many endemic species have increased in census size (Helenurm et al. 2005, Riley et al. 2010, Tierra Data Inc. 2013, Riley et al. 2016), and native plants have begun recolonizing more open areas (Wylie 2012, Tierra Data Inc. 2013). Although some taxa have been actively recovered, much of the observed change is the result of natural regeneration following the release from grazing pressure. While the observed demographic rebounds are positive and the biota's resiliency is expected to improve as native taxa return to pregrazing population sizes, it is unclear whether passive management will effectively safeguard the remaining genetic diversity.

Understanding the distribution of genetic diversity among island endemics is important for several reasons. First, it is possible that there has been adaptive divergence among island locations (Weigelt et al. 2015) and that individuals in different regions are adapted to different conditions. Although San Clemente Island is only $147 \mathrm{~km}^{2}$, it supports a number of different environments, from the cooler, moister southeast canyons to the hotter, drier western uplands. If genetically distinct plant populations have specialized to local conditions, several areas should be targeted for conservation to capture the range of adaptive divergence. Similarly, genetic mixing through augmentation or reseeding from distant populations should be avoided. Several current studies are attempting to assess the degree of genetic divergence between morphologically distinct taxa on the island (e.g., Acmispon argophyllus varieties [McGlaughlin et al. 2018 ] and Delphinium variegatum varieties [K. Helenurm unpublished data]). Second, some locations may be more genetically diverse or distinct. Identifying such locations allows prioritization of conservation efforts within the set of populations that best captures a taxon's genetic breadth (Volkmann et al. 2014). For example, Riley et al. (2010) found that Galium catalinense subsp. acrispum from San Clemente Island had high levels of genetic diversity for an island endemic, but only populations from 3 distinct areas on the island would need to be protected in order to capture the breadth of that diversity. In contrast, McGlaughlin et al. (2015) found that there was little genetic diversity within Sibara filifolia and that sampling only a few individuals would capture most of the genetic variation in San Clemente Island populations. Third, by identifying genetic patterns within island endemics, it may be possible to identify areas that are likely to support genetically diverse populations of more widespread taxa with similar life histories and dispersal mechanisms. Community-level restoration efforts in these areas may be particularly effective in maintaining the evolutionary potential of multiple taxa (Manel and Holderegger 2013, Tucker and Cadotte 2013, Vellend et al. 2014).

In this study we examine the patterns of divergence and diversity among populations of 2 endemic buckwheats (Eriogonum). Our goals are (1) to assess the level of genetic diversity within and among populations, (2) to determine whether there has been divergence among populations indicative of adaption or historically important refugia, and (3) to recommend conservation actions likely to preserve the evolutionary potential of the taxa.

\section{Methods}

\section{Study Organisms}

Sediment cores indicate that Eriogonum has been present in the Channel Islands flora since the shift from closed pine forests to more open scrub communities about 12,000 years ago (Anderson et al. 2010). Eriogonum giganteum var. formosum Brandegee (syn. E. giganteum subsp. formosum (K. Brandegee) P.H. Raven) and Ergionum grande var. grande Greene (syn. E. latifolium subsp. grande (Greene) S. Stokes, syn. E. nudum var. grande (Greene) Jeps), 2 shrubby buckwheats common in coastal bluff and island scrub communities (Schoenherr et al. 2003, Junak et al. 2007), are unique to the California Channel Islands and represent classic examples of island gigantism (Thorne 1969, Schoenherr et al. 2003) both in woodiness and overall size (50-250 cm; Costea and Reveal 2013) compared to mainland relatives. 
Eriogonum giganteum var. formosum is a San Clemente Island endemic variety of a species that also occurs on Santa Catalina and Santa Barbara Islands. Eriogonum giganteum is most closely related to the northern Channel Island endemic species Eriogonum arborescens Greene and more distantly related to the native California species Eriogonum fasciculatum Benth (Watson 1885, Raven 1967, Kempton 2012, Riley et al. 2016). Eriogonum grande var. grande is a California Channel Island endemic variety that also occurs on Santa Catalina Island and most of the northern islands. The species is closely related to the native California species Eriogonum latifolium Sm. (Kempton 2012).

There are no published studies on the reproductive ecology of the study taxa. Mating systems vary broadly within Eriogonum, ranging from genetic self-incompatibility to habitual selfing (Moldenke 1976). Both taxa have large floral displays of open bisexual flowers with pollen available to generalist pollinators (Montalvo 2004, M.E. McGlaughlin personal observation). Eriogonum, particularly E. fasciculatum, reportedly attracts a wide variety of beneficial insects (Junak et al. 1995, Junak and Wilken 1998, Morandin et al. 2011, James et al. 2014). One variety of $E$. grande endemic to the northern California Channel Islands, $E$. grande var. rubescens, is known to be selfcompatible but to require pollinator visitation for maximal seed set (McEachern et al. 1997). The importance of vegetative spread in the study taxa is also unknown. Eriogonum fasciculatum does produce adventitious roots (Little 1981), but no note about clonal spread was made in a study of $E$. arborescens establishment (Yelenik and Levine 2010a). Based on the available data and extensive field observations, it seems likely that both taxa are self-compatible but that vegetative spread is limited.

\section{Sampling and Microsatellite Amplification}

We sampled a total of 294 individuals of Eriogonum giganteum var. formosum and a total of 281 individuals of Eriogonum grande var. grande from 15 locations $(5$ shared and 5 unique to each taxon) across the island (Fig. 1). Sample sizes ranged from 8 individuals to 32 individuals per location (Table 1). Vouchers were not collected because these taxa have distinct morphologies, have been well sampled, and were collected from previously docu- mented sites. Fresh leaf tissue was stored at $-80{ }^{\circ} \mathrm{C}$ prior to extraction. Genomic DNA was extracted from frozen leaf tissue using a modified CTAB protocol (Doyle and Doyle 1987). Microsatellite primer pairs developed for Eriogonum giganteum (Riley et al. 2011, Riley 2012) were used to gather data for all individuals. Nine primer pairs (ERGR_43, EGIC_82, ERAR_85, ERGI_94, EGIC_96, ERGI_99, EGIC_110, EGIC__144, and ERAR _221) for Eriogonum giganteum var. formosum and 7 primer pairs (ERGR_20, ERGR_43, EGIC_82, ERAR_85, EGIC_110, ERTGR 162, and ERGR_308) for Eriogonum grande var. grande that amplified consistently and could be scored unambiguously for each taxon in preliminary studies were used for data collection. Amplification was carried out in $12-\mu \mathrm{L}$ reactions on an MJ Research PTC200 following the protocols in Riley et al. (2011). Amplification products were diluted with water and electrophoresed with GeneScan ${ }^{\mathrm{TM}} 500$ LIZ (Applied Biosystems) size standard on an Applied Biosystems 3500 Series Genetic Analyzer following the manufacturer's instructions. Fragments were sized with GeneMARKer ${ }^{\circledR}$ software (SoftGenetics, State College, PA).

\section{Microsatellite Diversity and Population Structure}

Null allele presence and size scoring errors were assessed for all loci in all sampling sites with Micro-Checker (Van Oosterhout et al. 2004). Site level parametersincluding the proportion of polymorphic loci, observed and expected heterozygosities under Hardy-Weinberg equilibrium (HWE), and fixation indices-were calculated with GenAlEx 6.5 (Peakall and Smouse 2012). Selfing estimates were calculated using BES (Redelings et al. 2015). Inbreeding coefficients for each sampling site were calculated with Genepop 4.2 (Raymond and Rousset 1995, Rousset 2008) based on allele identity. Deviations from HWE expectations and the presence of linkage disequilibrium (LD) between loci were also assessed with GENEPOP. Deviations from HWE expectations were considered significant at $P<0.01$ because the test statistics have been shown to underestimate the error rate (mean of type 1 and type 2 error rates) for both multiallelic data with rare genotypes and small sample sizes 


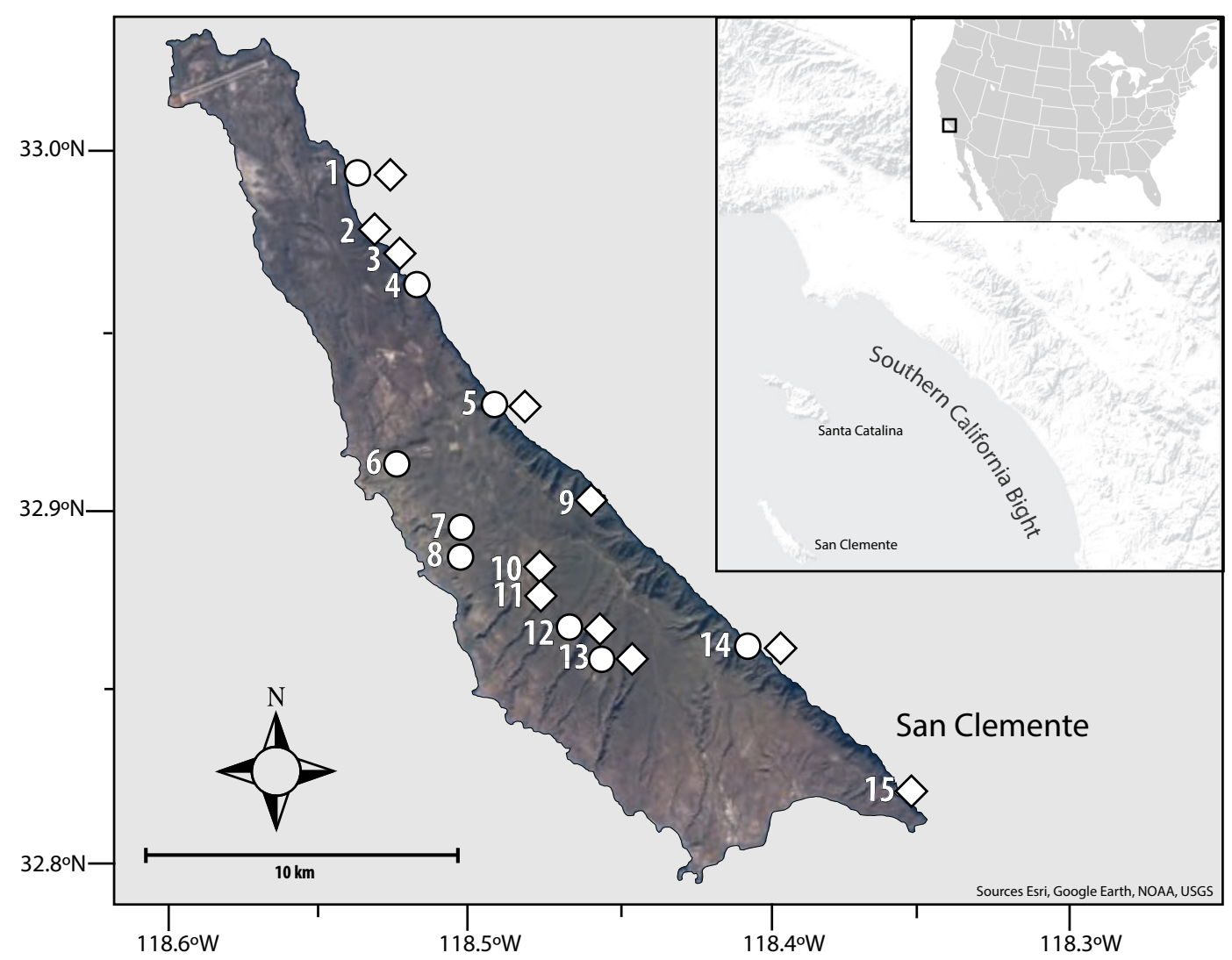

Fig. 1. Approximate sampling locations of Eriogonum giganteum var. formosum (circles) and E. grande var. grande (diamonds) on San Clemente Island. Sampling site designations and abbreviations: (1) BSC = Boy Scout Camp, (2) NP = Nots Pier, (3) M = Maple, (4) CHC = Chamish Canyon, (5) LT = Lemon Tank, (6) EP = Eel Point Canyon, (7) WR = Wall Rock Canyon, (8) W = Warren Canyon, (9) TD = Twin Dams, (10) WC = Waynuck Canyon, (11) MR = Middle Ranch, (12) BX = Box Canyon, (13) HC = Horse Canyon, (14) BR = Bryce Canyon, and (15) PY = Pyramid.

for several different tests of HWE (Emigh 1980, Lauretto et al. 2009).

Individual-centered networks were calculated in EDENETWORK v. 2.16 (Kivelä et al. 2011) using individual genotypes as nodes and the linear Manhattan distance measure as links. Networks were calculated with the default parameters of collapsed clones and thresholding of 2.00 to identify strongly clustered genotypes and to visualize patterns of connectivity. Sampling site-centered neighborjoining trees based on Nei's genetic distance were constructed in POPTREE2 (Takezaki et al. 2010) with 10,000 bootstrap replicates.

Bayesian estimation of population membership (K = 1-20) was implemented in STRUCTURE 2.3.4 (Pritchard et al. 2000, Falush et al. 2003, Hubisz et al. 2009) using flat priors under models of admixture and uncorrelated allele frequencies. After a burn-in of 100,000 steps, 20 independent runs of 300,000 steps were performed for each $\mathrm{K}$ with and without recessive alleles to account for the possibility of null alleles. The number of clusters was determined by examining the rate of change in $\mathrm{K}$ as calculated by STRUCTURE HARVESTER (Earl 2012) following the method of Evanno et al. (2005). Because selfing can inflate estimates of admixture and K, Bayesian estimation of population membership $(\mathrm{K}=$ 1-20) was repeated with INSTRUCT (Gao et al. 2007), which jointly infers $K$ clusters and cluster-specific selfing rates. The ancestry profiles output by INSTRUCT were analyzed in ОвSтRUст to determine the number of clusters and the proportion of the variability in the data explained by the ancestry assignments (Gayevskiy et al. 2014). 
TABLE 1. Microsatellite diversity within Eriogonum giganteum var. formosum and E. grande var. grande with sampling locations arranged from north to south for each taxon. $\mathrm{N}=$ number of individuals successfully amplified, $\mathrm{A}=$ alleles per locus, $\mathrm{AE}=$ effective alleles per locus, $\mathrm{AP}=$ private alleles, $\mathrm{P}=$ percentage of polymorphic loci, Ho $=$ observed heterozygosity, $\mathrm{HE}=$ expected heterozygosity, FIS = inbreeding coefficient, and S = selfing estimate. Sampling site abbreviations and locations are as in Fig. 1.

\begin{tabular}{|c|c|c|c|c|c|c|c|c|c|}
\hline \multicolumn{10}{|c|}{ Eriogonum giganteum var. formosum } \\
\hline Site & $\mathrm{N}$ & A & $\mathrm{AE}$ & AP & $\mathrm{P}$ & Но & $\mathrm{HE}$ & FIS & S \\
\hline $\mathrm{BSC}(1)$ & 30 & 2.33 & 1.39 & 2 & $88.9 \%$ & 0.14 & 0.22 & 0.357 & 0.477 \\
\hline $\mathrm{CHC}(4)$ & 32 & 1.89 & 1.21 & 1 & $55.6 \%$ & 0.15 & 0.13 & -0.131 & 0.159 \\
\hline $\mathrm{LT}(5)$ & 32 & 3.22 & 1.76 & 3 & $77.8 \%$ & 0.29 & 0.34 & 0.156 & 0.222 \\
\hline $\operatorname{TD}(9)$ & 32 & 2.33 & 1.46 & 3 & $66.7 \%$ & 0.23 & 0.22 & -0.010 & 0.154 \\
\hline WC $(10)$ & 29 & 1.78 & 1.18 & 2 & $66.7 \%$ & 0.10 & 0.12 & 0.191 & 0.273 \\
\hline $\operatorname{MR}(11)$ & 30 & 2.67 & 1.57 & 2 & $66.7 \%$ & 0.23 & 0.27 & 0.180 & 0.393 \\
\hline $\mathrm{BX}(12)$ & 27 & 2.56 & 1.33 & 2 & $66.7 \%$ & 0.16 & 0.19 & 0.164 & 0.387 \\
\hline $\mathrm{HC}(13)$ & 32 & 2.89 & 1.57 & 1 & $88.9 \%$ & 0.20 & 0.28 & 0.303 & 0.437 \\
\hline $\mathrm{BR}(14)$ & 29 & 3.44 & 1.79 & 4 & $77.8 \%$ & 0.31 & 0.34 & 0.108 & 0.169 \\
\hline PY (15) & 21 & 1.67 & 1.27 & 1 & $44.4 \%$ & 0.14 & 0.14 & -0.023 & 0.149 \\
\hline MEAN & 29.4 & 2.48 & 1.45 & 2.1 & $70.0 \%$ & 0.19 & 0.22 & 0.130 & 0.282 \\
\hline \multicolumn{10}{|c|}{ Eriogonum grande var. grande } \\
\hline Site & $\mathrm{N}$ & A & $\mathrm{AE}$ & AP & $\mathrm{P}$ & Но & $\mathrm{HE}$ & Fis & $\mathrm{S}$ \\
\hline $\mathrm{BSC}(1)$ & 30 & 2.00 & 1.33 & 2 & $66.7 \%$ & 0.16 & 0.18 & 0.141 & 0.368 \\
\hline $\mathrm{NP}(2)$ & 32 & 2.00 & 1.34 & 1 & $83.3 \%$ & 0.16 & 0.20 & 0.253 & 0.376 \\
\hline $\mathrm{M}(3)$ & 29 & 1.83 & 1.52 & - & $66.7 \%$ & 0.19 & 0.24 & 0.231 & 0.418 \\
\hline $\mathrm{LT}(5)$ & 31 & 1.83 & 1.27 & - & $83.3 \%$ & 0.15 & 0.17 & 0.147 & 0.318 \\
\hline $\operatorname{EP}(6)$ & 30 & 1.67 & 1.25 & 1 & $66.7 \%$ & 0.12 & 0.15 & 0.190 & 0.262 \\
\hline WR (7) & 32 & 1.83 & 1.41 & - & $66.7 \%$ & 0.20 & 0.22 & 0.074 & 0.271 \\
\hline $\mathrm{W}(8)$ & 32 & 2.83 & 1.63 & 5 & $100.0 \%$ & 0.28 & 0.32 & 0.147 & 0.352 \\
\hline $\mathrm{BX}(12)$ & 32 & 2.00 & 1.33 & - & $83.3 \%$ & 0.20 & 0.18 & -0.089 & 0.107 \\
\hline $\mathrm{HC}(13)$ & 8 & 1.17 & 1.02 & - & $16.7 \%$ & 0.02 & 0.02 & 0.000 & 0.426 \\
\hline $\mathrm{BR}(14)$ & 26 & 2.00 & 1.61 & - & $83.3 \%$ & 0.34 & 0.34 & 0.022 & 0.194 \\
\hline MEAN & 28.1 & 1.92 & 1.37 & 0.9 & $71.7 \%$ & 0.18 & 0.20 & 0.112 & 0.309 \\
\hline
\end{tabular}

\section{RESULTS}

All loci amplified successfully in all sampling sites. In tests for scoring errors and the presence of null alleles, 9 loci (ERGR_20, ERGR_43, EGIC_82, ERAR_85, EGIC_96, ERGI_99, EGIC ERAR_221) had heterozygote deficiencies possibly suggesting null alleles in $1-5$ sampling sites. In all cases more than half of the alleles fell into a single size class. One locus, EGIC_110, showed evidence of homozygote excess and stutter in 5 out of $10 \mathrm{E}$. grande var. grande sampling sites and high (18\%) amplification failure in a single sampling site (Nots Pier). The same locus amplified consistently in E. giganteum var. formosum and showed evidence of homozygote excess-but no potential stutter-in 3 sampling sites (Boy Scout Camp, Horse Canyon, and Lemon Tank) that had low variability and homozygote excesses for 2 (Boy Scout Camp and Horse Canyon) or 3 (Boy Scout Camp, Horse Canyon, and Lemon Tank) other loci. There was no evidence of large allele dropout at any of the loci.

Subsequent analyses were run without EGIC_110 for E. grande var. grande and without correcting for null alleles. The high amplification success for other loci $(0-2$ failures in 281-294 reactions) and negligible evidence for large allele dropout, scoring errors, and null alleles in the retained loci suggest that our data allow reliable inference about the population genetics of these Eriogonum species.

Microsatellite diversity was generally low within both taxa (Table 1). Within E. giganteum var. formosum sampling sites, the number of alleles per locus ranged from 1.67 to $3.44(\bar{x}=$ 2.48) while the number of effective alleles per locus ranged only from 1.18 to $1.79(\bar{x}=1.45)$; the expected heterozygosities were all below 0.35 (Table 1). Every sampling site was fixed for a single allele in at least one locus and all sites either failed to meet HWE expectations (multilocus exact test: $P<0.01$ ) or were fixed for a single allele in at least a third of the amplified loci (Table 1). Sampling sites were 


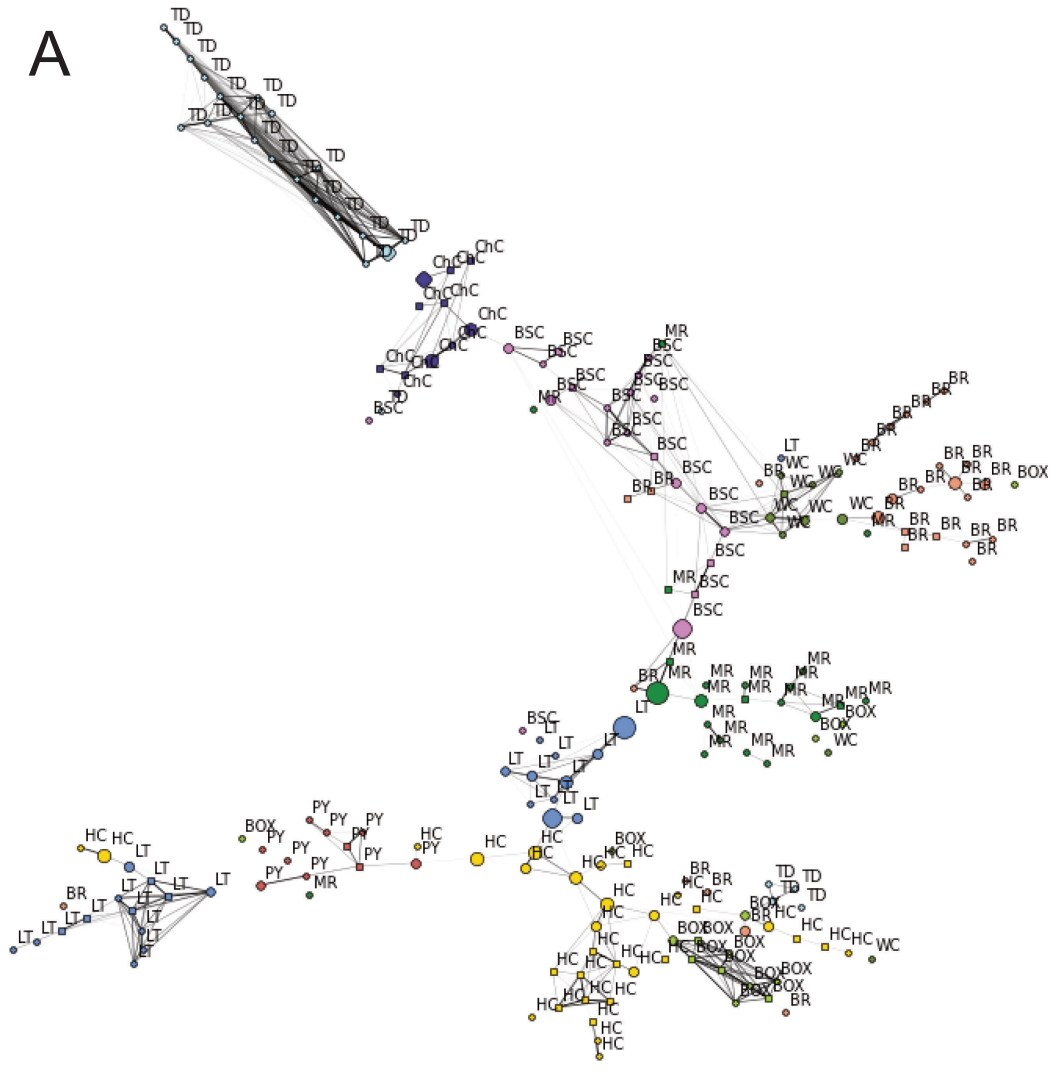

Fig. 2. EDENETwORK individual-centered networks using individual genotypes as nodes and the linear Manhattan distance measure as links, with thresholding set at 2.00: A, Eriogonum giganteum var. formosum; B (p. 729), E. grande var. grande. Sampling site abbreviations are as in Fig. 1.

relatively differentiated, with all harboring at least one unique allele. Inbreeding coefficients (FIS) varied broadly from -0.131 to $0.357(\bar{x}$ $=0.130)$, while selfing estimates ranged from 0.149 to 0.477 .

Microsatellite diversity was even lower within E. grande var. grande (Table 1). This could be due, in part, to fewer (6 vs. 9 ) and less variable (up to 5 alleles vs. up to 15 alleles) sampled loci, although private alleles were detected at most (5 and 7) loci in each data set. All E. grande var. grande sites were characterized by few alleles per locus $(1.17-2.83, \bar{x}=$ $1.92)$, very few effective alleles per locus $(1.02-1.63, \bar{x}=1.37)$, and low expected heterozygosities $(0.02-0.34, \bar{x}=0.20)$. Only one sampling site was polymorphic for all loci, and only 2 sites met HWE expectations (multilocus exact test; $P<0.01$ ). Sampling sites were relatively undifferentiated, with few sites harboring unique alleles. Inbreeding coefficients ranged from -0.089 to $0.253(\bar{x}=$ 0.112 ), while selfing estimates ranged from 0.107 to $0.426(\bar{x}=0.309)$. Of the 3 loci shared between E. giganteum var. formosum and $E$. grande var. grande, we detected 2 alleles (163 and 166) in common at 1 locus (ERGR 43) in 2 E. grande var. grande heterozygotes that were also segregating in our E. giganteum var. formosum samples. That is, 2 of the approximately 3500 alleles sampled at these 3 loci were shared between the 2 taxa. This result provides little evidence for hybridization between E. giganteum var. formosum and $E$. grande var. grande.

Individual-centered networks indicated modest connectivity among $E$. giganteum var. formosum (Fig. 2A) and high connectivity among E. grande var. grande (Fig. 2B). There were several distinct unconnected clusters of genotypes among the former, including some clusters composed mostly of individuals from 


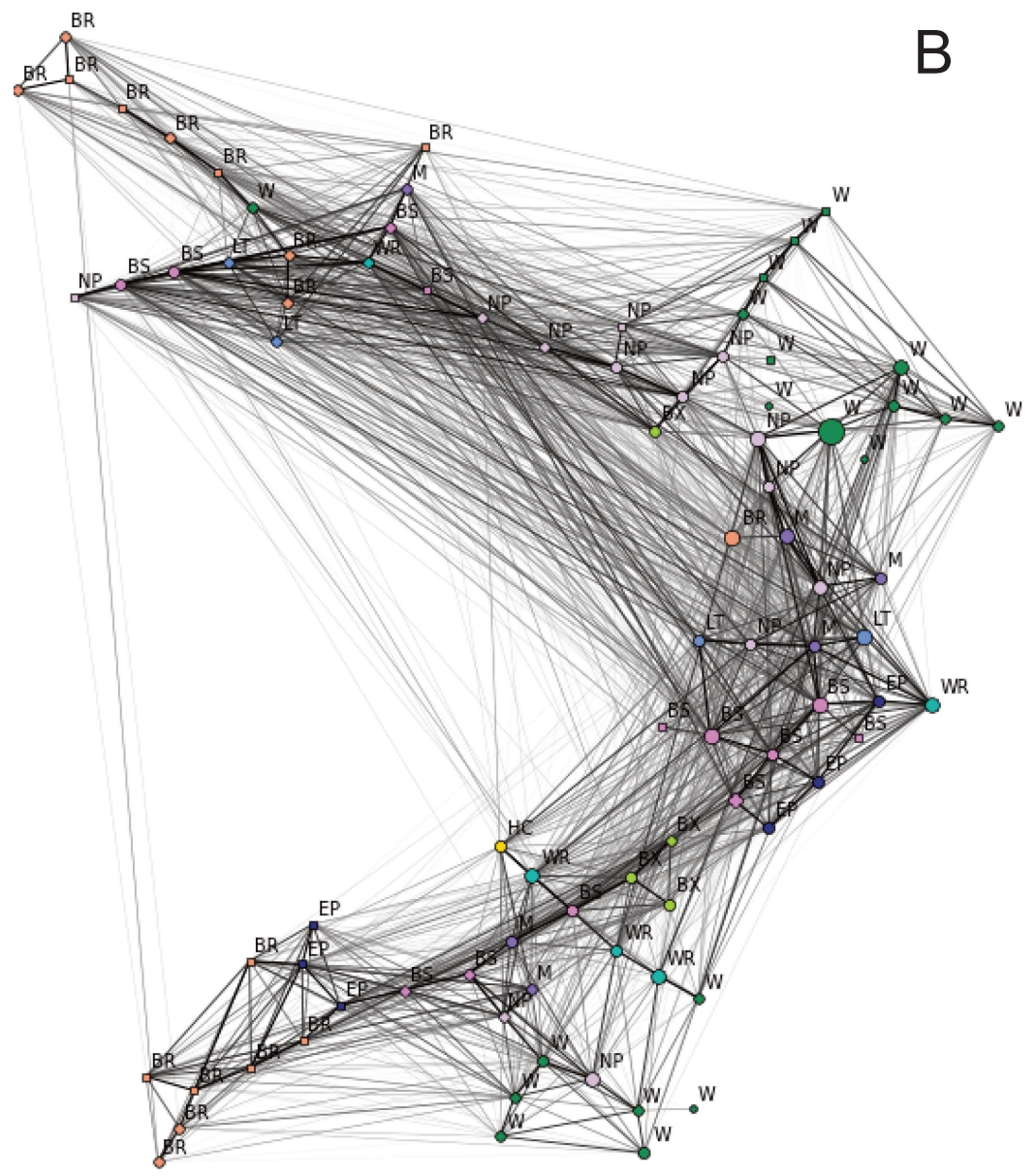

Fig. 2. Continued.

single sampling sites (e.g., Chamish Canyon, Horse Canyon, Pyramid, and Twin Dams), indicating genetic differentiation between sites (Fig. 2A). Among the latter, there were no well-resolved clusters, and individuals from single sampling sites were generally found throughout the network (Fig. 2B). Neighborjoining phenograms with bootstrap resampling based on Nei's genetic distances between sampling sites were poorly resolved (Fig. 3). Among E. giganteum var. formosum, one west-central clade was weakly supported $(50 \%$ of bootstrap replicates) and one northeast clade was more strongly supported (Fig. 3A). In the latter, Twin Dams was inferred to be a sister to Chamish Canyon (72\% of bootstrap replicates), and Twin Dams plus Chamish Canyon was inferred to be a sister to Boy Scout Camp (73\% of bootstrap replicates).
Among E. grande var. grande, no clade was recovered in more than $50 \%$ of the bootstrap replicates (Fig. 3B).

The results of STRUCTURE with and without recessive alleles were consistent in the assignment of individuals and optimal numbers of clusters, indicating that the analyses were not influenced by the presence of null alleles. STRUCTURE HARVESTER consistently inferred fewer populations than INSTRUCT (E. giganteum var. formosum, $\mathrm{K}=4$ vs. $10 ; E$. grande var. grande, $\mathrm{K}=4$ vs. 7 , data not shown). ОвSтRUCT found the highest support for 3 populations within both $E$. giganteum var. formosum $\left(\mathrm{R}^{2}=0.93, P<\right.$ $0.0001)$ and $E$. grande var. grande $\left(\mathrm{R}^{2}=0.60\right.$, $P<0.0001)$. The 3 inferred populations were less admixed within E. giganteum var. formosum (average estimate of single population 

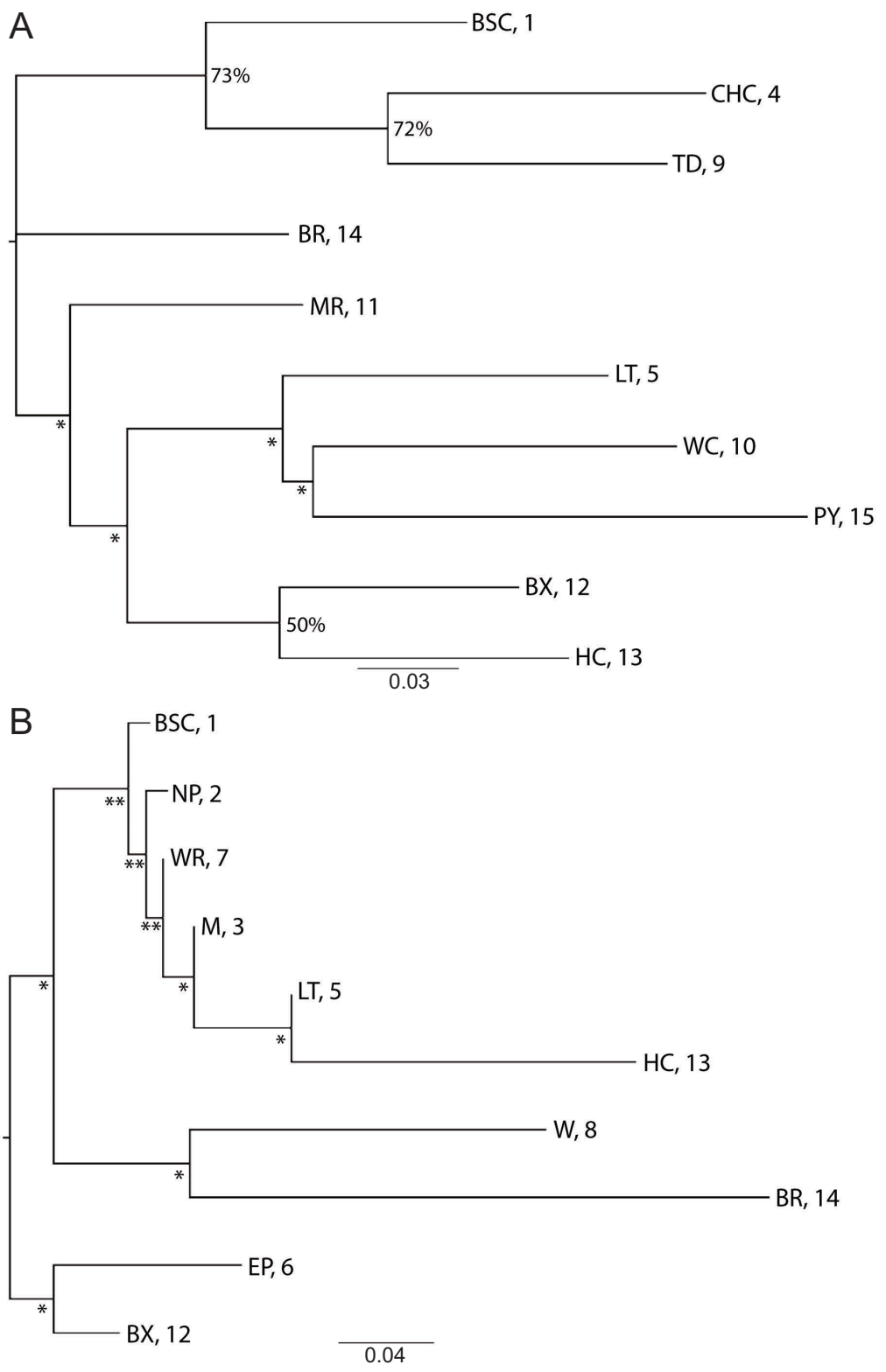

Fig. 3. Neighbor-joining phenograms based on Nei's genetic distance: A, Eriogonum giganteum var. formosum sampling sites; B, E. grande var. grande sampling sites. Bootstrap values over $50 \%$ are reported to the right of nodes. Bootstrap values below $50 \%(*)$ and $25 \%(* *)$ are indicated below branches. Sampling site abbreviations and locations are as in Fig. 1.

membership $=0.925$; Fig. $4 \mathrm{~A})$ than within $E$. grande var. grande (average estimate of single population membership $=0.807$; Fig. $4 \mathrm{~B}$ ). Similarly, the ОвSтRUCT plots of canonical discriminant analysis reveal greater separation between inferred populations of $E$. giganteum var. formosum (Fig. 5A) than E. grande var. grande (Fig. 5B).
The populations estimated by STRUCTURE and InStruct and analyzed in OвStruct did not correspond strictly to geographically clustered sampling sites (Figs. 1, 4, 5). Within $E$. giganteum var. formosum, 3 of the 4 northern sites on the east side of the island were recovered together, as were 4 of the 5 central sites ( 3 on the west side and one on the east side of 
A.

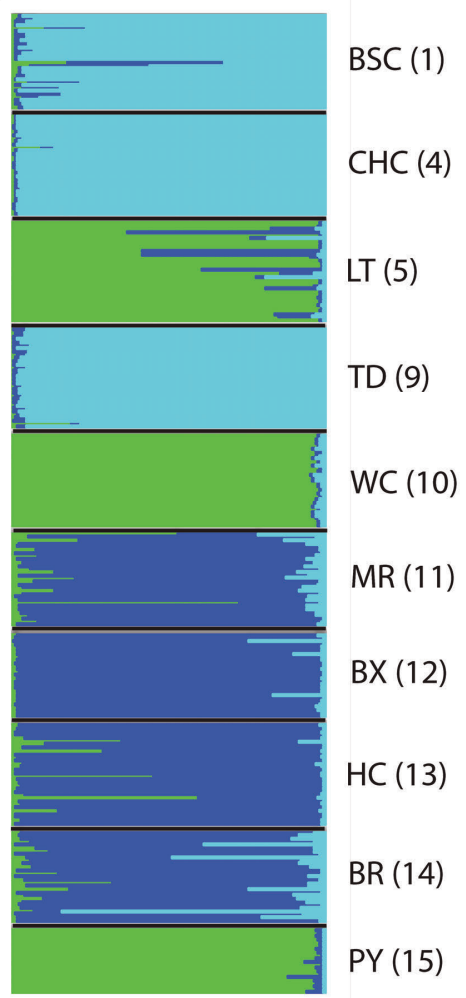

B.

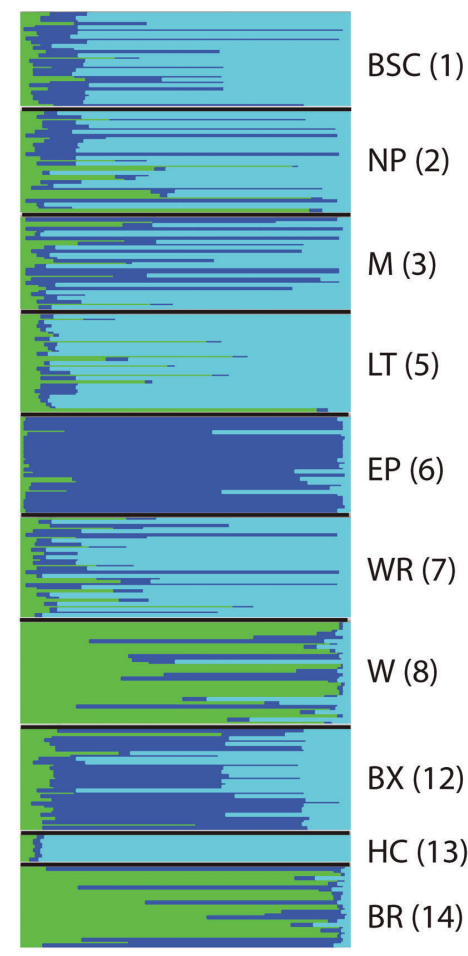

Fig. 4. Results of InStruct Bayesian population assignments at $\mathrm{K}=3$ : A, Eriogonum giganteum var. formosum; B, E. grande var. grande. Sampling site abbreviations and locations are as in Fig. 1.

the island). The remaining inferred population consisted of individuals from northern-central and southern sampling sites and both the west and east sides of the island. Within E. grande var. grande, all of the northern sites on the east side of the island were recovered with a central site from the west side of the island; 2 central sites from the west side were recovered together but not with the intervening population, which was instead clustered with a southern site from the east side of the island. Within both taxa, geographically close sampling sites were often inferred to be in different populations (e.g., Waynuck Canyon, Middle Ranch, Warren Canyon, and Wall Rock Canyon; Figs. 1, 4, 5).

\section{Discussion}

Our analyses indicate that both $E$. giganteum var. formosum and E. grande var. grande have low levels of genetic diversity, even for island populations which are frequently less diverse than related mainland populations (Frankham 1997, Franks 2010; but see GarcíaVerdugo et al. 2015). While we cannot be certain of the impacts of specific historic habitat perturbations on genetic diversity, California Channel Island populations might be expected to have low genetic diversity as a result, in part, of the widespread herbivoreinduced demographic declines of the past 150 years, causing these Eriogonum species to be genetically depauperate. Among San Clemente Island taxa with published microsatellite diversity estimates, only Sibara filifoliawhich was presumed extinct for decades-is less diverse (Table 2). This is particularly surprising because Eriogonum species are expected to be buffered from some effects of the demographic bottleneck by their perennial habit and relatively long generation times (Hairston et al. 1996, Petit and Hampe 2006, Riley et al. 2010).

The low diversity within these Eriogonum species could be partially due to inbreeding 


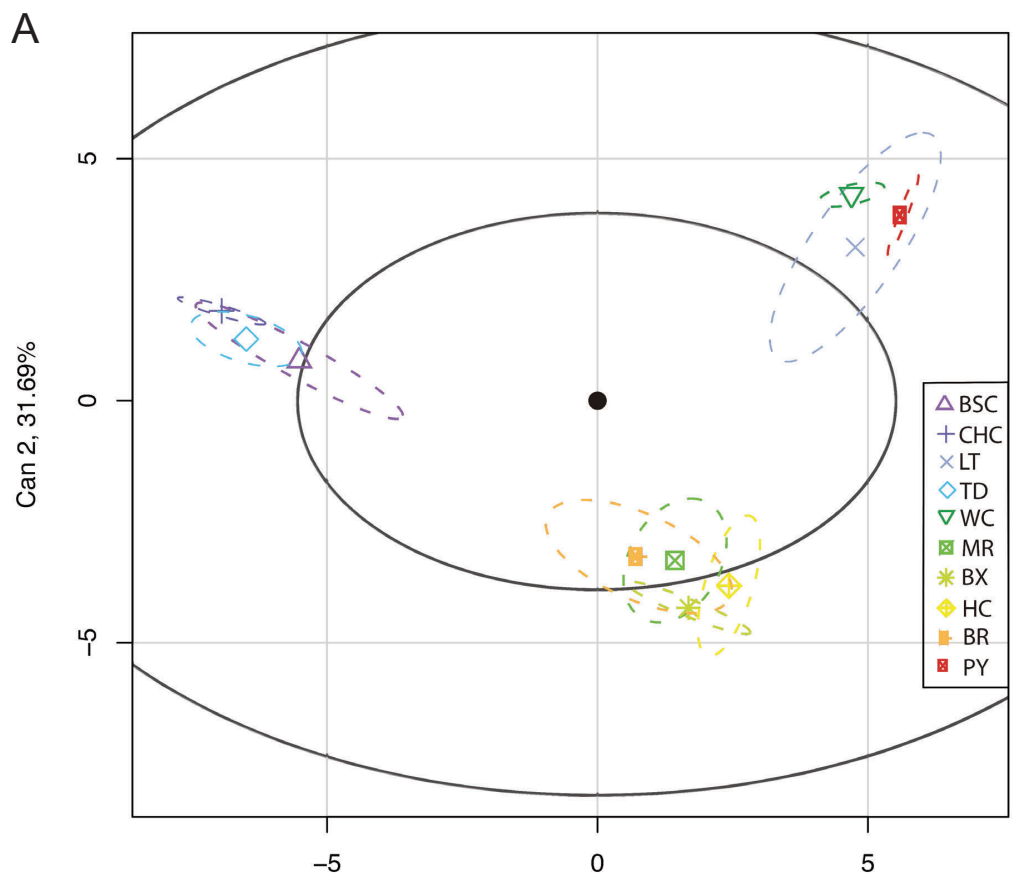

Can $1,66.97 \%$

B

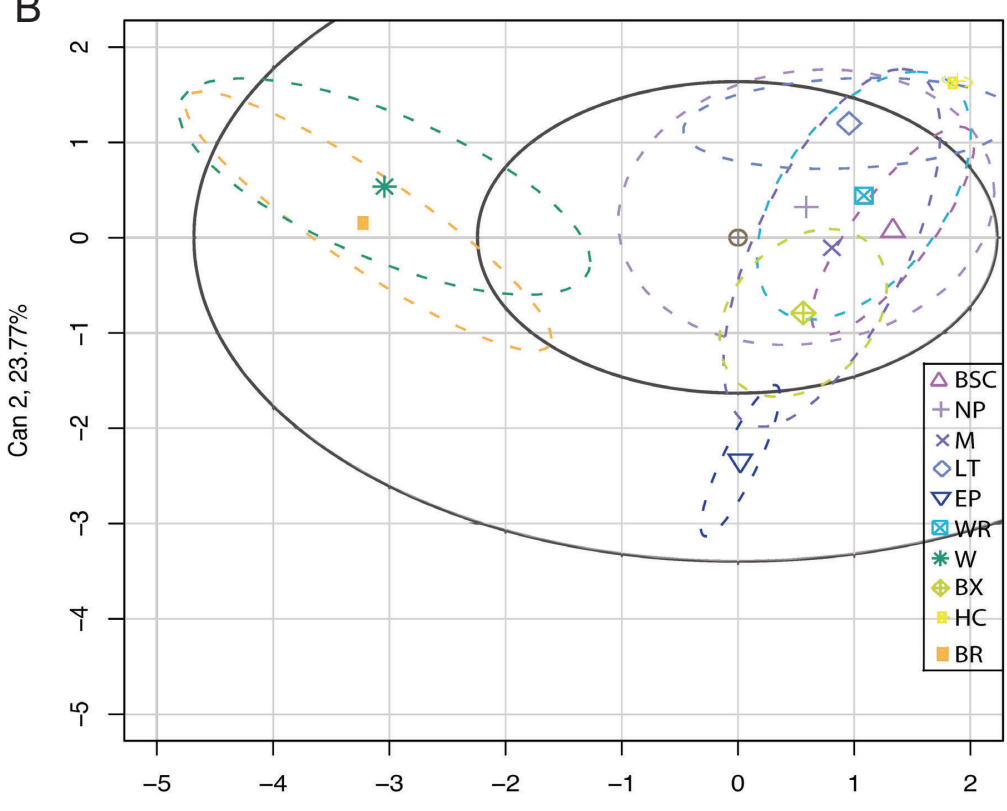

Can $1,65.63 \%$

Fig. 5. ОвSтRUст canonical discriminant analysis plots of the median and 50\% ellipse for each sampling site based on InSTRUCT Bayesian population assignments at $\mathrm{K}=3: \mathbf{A}$, E. giganteum var. formosum; $\mathbf{B}$, E. grande var. grande. Sampling site abbreviations and locations are as in Fig. 1. 
TABle 2. Microsatellite diversity of San Clemente Island taxa. $\mathrm{AE}=$ effective alleles per locus, $\mathrm{HE}=$ expected heterozygosity, and FIs = inbreeding coefficient. Data sources: Acmispon, McGlaughlin et al. (2014); Crossosoma, Wallace and Helenurm (2009); Galium, Riley et al. (2010); Lithophragma, Furches et al. (2009); and Sibara, McGlaughlin et al. (2015).

\begin{tabular}{lccr}
\hline Taxon & $\mathrm{AE}$ & $\mathrm{HE}$ & \multicolumn{1}{c}{ FIS } \\
\hline Acmispon argophyllus & 2.0 & 0.353 & 0.422 \\
Acmispon dendroideus & 2.3 & 0.417 & 0.314 \\
$\begin{array}{l}\text { Crossosoma californicum } \\
\text { Eriogonum giganteum }\end{array}$ & 1.5 & 0.272 & -0.135 \\
$\quad 1.5$ & 0.224 & 0.238 \\
$\quad$ var. formosum & & & \\
$\quad$ riogonum grande & 1.4 & 0.202 & 0.223 \\
$\quad$ var. grande & & & \\
Galium catalinense & 2.6 & 0.493 & 0.015 \\
$\quad \begin{array}{l}\text { Lithophragma maximum } \\
\text { Sibara filifolia }\end{array}$ & 1.5 & 0.229 & 0.008 \\
& 1.0 & 0.017 & 0.851 \\
\hline
\end{tabular}

through both self-mating and near-neighbor matings. The island taxa may be largely outcrossing because they have large floral displays with open bisexual flowers and readily available pollen that attract a wide variety of insects (Junak et al. 1995, Junak and Wilken 1998, McGlaughlin personal observation). Individual plants may be surrounded by close relatives, however, because the seeds are likely to be primarily gravity dispersed (Junak and Wilken 1998). Inbreeding may also be exacerbated by selfing. Eriogonum species, such as the related island taxon $E$. grande var. rubescens, are often self-compatible but may require pollinator visitation for maximal seed set (Moldenke 1976, McEachern et al. 1997). Regular uniparental inheritance is consistent with our Bayesian estimates of selfing, which ranged from 0.107 (E. grande var. grande, Box Canyon) to 0.477 (E. giganteum var. formosum, Boy Scout Camp; Table 1).

The steady loss of heterozygosity associated with self-compatibility and limited dispersal would have been accelerated if these Eriogonum species were unable to take advantage of either of the 2 types of refuges available during the period of goat infestation. The most apparent refuges exploited by San Clemente Island plants were the steep canyon walls. Botanists working in the late 1900s noted that although much of the island had been denuded by goats or converted to vast Opuntiadominated scrublands, native plants could be found clinging to steep cliffs (Ross et al. 1996). While the largest populations of Eriogonum following goat removal were located in relatively inaccessible rocky canyons, the plants generally grow on or near the canyon floors. In contrast, Galium catalinense var. acrispum, which has a much higher genetic diversity, historically occurred on steep rocky walls where both grazing pressure and competition from invasive plants was lower (Raven 1963, Beauchamp 1987).

The second common refuge available was the soil seed bank. Although the high goat density was associated with extensive trampling and destruction of unprotected aboveground plant parts, some plants seem to have persisted in the soil. For example, several taxa that were presumed extinct for decades because they were not seen aboveground have been rediscovered on San Clemente Island since goat removal (Wallace et al. 2006, McGlaughlin et al. 2015). Similarly, new and disjunct populations of several additional taxa have been discovered (Tierra Data Inc. 2013). In general, annual plants in variable and arid environments create a persistent seed bank which acts to buffer populations and preserve genetic variability (Evans and Dennehy 2005). In contrast, perennial plant populations are often buffered by overlapping generations of aboveground individuals (Tuljapurkar and Wiener 2000, Saatkamp et al. 2014).

The extent of seed dormancy and the duration of seed viability is highly variable between and within annual and perennial plants (Rees 1996). For example, in viability studies of California Channel Island plants, Crossosoma californicum had $44 \%$ germination success after 50 years in storage while $E$. giganteum var. giganteum had $43 \%$ germination success after only 22 years in storage (Wall 2008). Although no studies of seed persistence have been published for these San Clemente Island Eriogonum species, studies of seed dormancy within the genus suggest that most seeds germinate the season after they mature (Keeley 1991, Meyer and Paulsen 2000). It seems likely that any seed bank containing these Eriogonum species at the onset of intensive grazing was largely exhausted prior to herbivore removal. In that case, little accumulation of diversity is expected to accompany demographic expansion.

The pattern of divergence seen among $E$. grande var. grande sampling locations could reflect underlying adaptive divergence to local conditions but seems more likely to reflect drift among fragmented populations. Overall 
there are few alleles per locus $(3-5, \bar{x}=3.5)$ and those alleles are shared among most sites, as is expected of a formerly large and panmictic population. Inferred populations are relatively admixed (Fig. 4B), and the recovered genetic divisions are based on allele frequency differences rather than private alleles. The differences among E. giganteum var. formosum sampling sites, however, are more pronounced. Overall there are far more alleles per locus $(2-15, \bar{x}=6.9)$, and most alleles are shared only among a subset of sites. Inferred populations have little admixture (Fig. 4A), and recovered genetic breaks are based on both the frequencies of shared alleles and the presence of private alleles. This pattern is consistent with adaptive divergence among $E$. giganteum var. formosum sampling locations, recently established populations with low levels of migration (Giles and Goudet 1997), and longstanding drift among locations that were relatively isolated prior to intensive grazing. Information on absolute population ages is lacking, but there is no indication in the literature that E. giganteum var. formosum populations are expected to be substantially younger than E. grande var. grande populations. Greater isolation among populations may be likely because $E$. giganteum var. formosum maintains smaller populations than $E$. grande var. grande (McGlaughlin personal observation).

The divergent population genetic patterns between E. grande var. grande and E. giganteum var. formosum suggest that different management strategies are required to maintain the genetic diversity of each taxon. Within $E$. grande var. grande, for example, there is little evidence that genetic diversity will increase rapidly with demographic expansion. Although the private alleles recovered might increase in frequency and spread to other populations with the reestablishment of pollinator networks, there are few total alleles per locus. Most of the diversity recovered in our study could be maintained by focusing on a few central sampling sites that represent all of the inferred populations (e.g., Eel Point Canyon, Wall Rock Canyon, Warren Canyon; Figs. 1, 4B) and include the majority of private alleles (Table 1). A conservative management plan, however, would include more distant sites (e.g., the other 2 sites with above-average $\mathrm{He}$, Maple and Bryce Canyon, or the other 2 sites with private alleles, Nots Pier and Boy Scout
Canyon; Table 1) to buffer the taxon from precipitous decline due to small-scale environmental stochasticity. In contrast, E. giganteum var. formosum holds more variability among sampling sites. Although individual sites are genetically depauperate, most loci have many alleles, and maintaining several sites across the island (e.g., Boy Scout Camp, Lemon Tank, Twin Dams, Middle Ranch, and Bryce Canyon; Fig. 1) would be necessary to capture most of the private alleles held within each inferred population (Table 1, Fig. 4A). With the addition of Horse Canyon, these would include all of the sites with aboveaverage $\mathrm{HE}$ but not all sites with private alleles (Table 1, Fig. 4A).

\section{Conclusions}

The data suggest that the perennial shrubs on San Clemente Island may have suffered more than anticipated from the severe population declines of the late 19th and 20th centuries. Although related mainland Eriogonum species do not have strong dormancy mechanisms (Montalvo 2004) or an apparent seed bank (DeFalco et al. 2009), both island and mainland Eriogonum species are known to be successful early colonists of disturbed areas (Allen et al. 2000, Montalvo 2004, Corry et al. 2009). This colonization ability among island Eriogonum species has allowed substantial demographic rebound (Corry 2006), apparently without an accompanying rebound in genetic diversity. Consequently, seemingly robust populations may remain vulnerable to genetic erosion, inbreeding depression, and increased extinction risk as a result of low effective population sizes (Frankham 2005, Traill et al. 2007). If this pattern is common, the observed expansion of native shrub communities may not justify a passive recovery approach as pursued on other California Channel Islands (Beltran et al. 2014). Rather, recovery should focus on actively increasing population sizes not only to maintain current genetic diversity but also to enhance the adaptive potential of these species (Jump et al. 2009).

As data sets from additional species on San Clemente Island become available, it may be possible to determine whether populations experiencing a demographic rebound show a general pattern of lacking genetic diversity. Similarly, such data might be used 
at a landscape scale to identify regions that have retained greater integrity or are particularly important in gene flow networks (Manel and Holderegger 2013). In the meantime, cost-effective methods of increasing the census size of current populations, such as the supplemental watering of seedlings and young plants during drought years (Padgett et al. 2000, McEachern et al. 2009, Yelenik and Levine 2010a), seem warranted both to preserve the evolutionary potential of Eriogonum and to bolster other recovery efforts. Expanding Eriogonum populations, which are visited by a variety of vagile pollinators (Junak et al. 1995, Junak and Wilken 1998), will support more robust pollinator networks and a more resilient flora (Kaiser-Bunbury et al. 2010). Furthermore, because Eriogonum individuals frequently act as nurse plants (Corry et al. 2009), larger populations will provide other native plants better access to high-quality microhabitats. Because Eriogonum seems to alter the soil nutrient profile and limit the growth of nonnative grasses (Corry et al. 2009, Yelenik and Levine 2010b, 2011), targeting Eriogonum may help recover the native understory, which has not rebounded as quickly or completely as the shrub communities (Wylie 2012, Beltran et al. 2014).

\section{ACKNOWLEDGMENTS}

This research was funded by a United States National Science Foundation award to L. Riley (DEB-0910059) and the Natural Resource Office, Staff Civil Engineer, Naval Air Station, North Island, San Diego, California. The U.S. Navy provided access and logistical support for all sampling on San Clemente Island. S. Junak and J. Dunn helped to collect specimens in the field. N. Britten assisted with DNA extraction. H. Britten provided helpful comments on a previous version of the manuscript.

\section{Literature Cited}

Allen, E.B., S.A. Eliason, V.J. Marquez, G.P. Schultz, N.K. Storms, C.D. Stylinski, T.A. Zink, and M.F. ALLEN. 2000. What are the limits to restoration of coastal sage scrub in Southern California? Pages 253-262 in J.E. Keeley, M. Baer-Keeley, and C.J. Fotheringham, editors, 2nd Interface between ecology and land development in California. USGS Report 00-62, Western Ecological Research Center, U.S. Geological Survey.

Anderson, R.S., S. StarkatT, and R.M.B. Jass. 2010. Fire and vegetation history on Santa Rosa Island Channel
Islands and long-term environmental change in southern California. Journal of Quaternary Science 255:782-797.

BALDWIN, B.G. 2014. Origins of plant diversity in the California Floristic Province. Annual Review of Ecology, Evolution, and Systematics 45:347-369.

Beauchamp, R.M. 1987. Endangered and candidate plant status inventory, San Clemente Island, Los Angeles County, California. Pacific Southwest Biological Services, National City, CA.

Beltran, R.S., N. Kreidler, D.H. Van Vuren, S.A. Morrison, E.S. Zavaleta, K. Newton, B.R. TerSHY, AND D.A. CROLL. 2014. Passive recovery of vegetation after herbivore eradication on Santa Cruz Island, California. Restoration Ecology 22: 790-797.

Berglund, H., J. Järemo, and G. Bengtsson. 2009. Endemism predicts intrinsic vulnerability to nonindigenous species on islands. American Naturalist 174:94-101.

Bowen, B.W., and J.O.E. Roman. 2005. Gaia's handmaidens: the Orlog model for conservation biology. Conservation Biology 19:1037-1043.

Bowen, L., AND D. Van Vuren. 1997. Insular endemic plants lack defenses against herbivores. Conservation Biology 11:1249-1254.

Brumbaugh, R.W. 1980. Recent geomorphic and vegetal dynamics on Santa Cruz Island, California. Pages 139-158 in D.M. Power, editor, The California Islands: proceedings of a multidisciplinary symposium. Santa Barbara Museum of Natural History, Santa Barbara, CA.

Caujapé-Castells, J., A. Tye, D.J. Crawford, A. SantosGuerra, A. Sakai, K. Beaver, W. Lobin, F.V. Florens, M. Moura, R. Jardim, and I. Gómes. 2010. Conservation of oceanic island floras: present and future global challenges. Perspectives in Plant Ecology, Evolution and Systematics 12:107-129.

Corry, P.M. 2006. Vegetation dynamics following grazing cessation on the Channel Islands California. Doctoral dissertation, University of North Carolina Chapel Hill, NC.

Corry, P.M., A.K. McEachern, C.C. Damiani, and D.K. GARCELON. 2009. Patterns in post-grazing vegetation changes among species and environments, San Miguel and Santa Barbara Islands. Pages 182-183 in C.C. Damiani and D.K. Garcelon, editors, Proceedings of the Seventh California Islands Symposium. Institute for Wildlife Studies, Arcata, CA.

Costea, M., and J.L. Reveal. 2013. Eriogonum. In: Jepson Flora Project, editors, Jepson eFlora. [Accessed 15 November 2014]. http://ucjeps.berkeley.edu/cgibin/get_IJM.pl?tid=24695

DeFalco, L.A., T.C. Esque, J.M. Kane, and M.B. NickLAS. 2009. Seed banks in a degraded desert shrubland: influence of soil surface condition and harvester ant activity on seed abundance. Journal of Arid Environments 73:885-893.

Doyle, J.J., AND J.L. DoYLE. 1987. A rapid DNA isolation procedure for small quantities of fresh leaf tissue. Phytochemical Bulletin 191:11-15.

EARL, D.A. 2012. STRUCTURE HARVESTER: a website and program for visualizing STRUCTURE output and implementing the Evanno method. Conservation Genetics Resources 4:359-361.

Emigh, T.H. 1980. A comparison of tests for HardyWeinberg equilibrium. Biometrics 36:627-642. 
Evans, M.E., And J.J. Dennehy. 2005. Germ banking: bet hedging and variable release from egg and seed dormancy. Quarterly Review of Biology 80:431-451.

Evanno, G., S. Regnaut, and J. Goudet. 2005. Detecting the number of clusters of individuals using the software STRUCTURE: a simulation study. Molecular Ecology 14:2611-2620.

Falush, D., M. Stephens, J.K. Pritchard. 2003. Inference of population structure: extensions to linked loci and correlated allele frequencies. Genetics 164: $1567-1587$.

Forest, F., K.A. Crandall, M.W. Chase, and D.P. Faith. 2015. Phylogeny, extinction and conservation: embracing uncertainties in a time of urgency. Philosophical Transactions of the Royal Society of London, Series B 370:20140002.

Forest, F., R. Grenyer, M. Rouget, T.J. Davies, R.M. Cowling, D.P. Faith, A. Balmford, J.C. Manning, S. Procheș, M. van der Bank, and G. Reeves, 2007. Preserving the evolutionary potential of floras in biodiversity hotspots. Nature 445:757-760.

Frankham, R. 1997. Do island populations have less genetic variation than mainland populations? Heredity 78:311-327.

Frankham, R. 2005. Genetics and extinction. Biological Conservation 126:131-140.

FranKs, S.J. 2010. Genetics, evolution, and conservation of island plants. Journal of Plant Biology 53:1-9.

Furches, M.S., L.E. Wallace, and K. Helenurm. 2009. High genetic divergence characterizes populations of the endemic plant Lithophragma maximum (Saxifragaceae) on San Clemente Island. Conservation Genetics 10:115-126.

GaO, H., S. Williamson, and C.D. Bustamante. 2007. A Markov chain Monte Carlo approach for joint inference of population structure and inbreeding rates from multilocus genotype data. Genetics 176: $1635-1651$.

García-Verdugo, C., M. Sajeva, T. La Mantia, C. HarRouni, F. Msanda, and J. Caujapé-Castells. 2015. Do island plant populations really have lower genetic variation than mainland populations? Effects of selection and distribution range on genetic diversity estimates. Molecular Ecology 24:726-741.

Gayeviskiy, V., S. Klaere, S. KNight, and M.R. Goddard. 2014. ObStruct: a method to objectively analyse factors driving population structure using Bayesian ancestry profiles. PLOS ONE 9:e85196.

Giles, B.E., AND J. GOUDET. 1997. Genetic differentiation in Silene dioica metapopulations: estimation of spatiotemporal effects in a successional plant species. American Naturalist 149:507-526.

Hairston, N., Jr., S. Ellner, and C. Kearns. 1996. Overlapping generations: the storage effect and the maintenance of biotic diversity. Pages 109-143 in O.E. Rhodes, R.K. Chesser, and M.H. Smith, editors, Population dynamics in ecological space and time. University of Chicago Press, Chicago, IL.

Helenurm, K., R. West, and S.J. Burckhalter. 2005. Allozyme variation in the endangered insular endemic Castilleja grisea. Annals of Botany 95:1221-1227.

Hubisz, M.J., D. Falush, M. Stephens, and J.K. PritchARD. 2009. Inferring weak population structure with the assistance of sample group information. Molecular Ecology Resources 9:1322-1332.

James D.G., L. Seymour, G. Lauby, and K. Buckley. 2014. Beneficial insects attracted to native flowering buckwheats (Eriogonum Michx) in central Washington. Environmental Entomology 43:942-948.

JoHnSON, D.L. 1975. New evidence on the origin of the fox, Urocyon littoralis clementae, and feral goats on San Clemente Island, California. Journal of Mammalogy 56:925-928.

Jump, A.S., R. Marchant, and J. Peñuelas. 2009. Environmental change and the option value of genetic diversity. Trends in Plant Science 14:51-58.

Junak, S., W.L. Halvorson, C.A. Schwemm, and T. KeEnEy. 1995. Sensitive plants of San Nicolas Island California phase 1. Technical Report No. 51, United States Geological Survey, Cooperative Park Studies Unit, Tucson, AZ

Junak, S., D.A. Knapp, J.R. Haller, R. Philbrick, A. Schoenherr, and T. Keeler-Wolf. 2007. The California Channel Islands. Pages 229-252 in M. Barbour, T. Keeler-Wolf, and A.A. Schoenherr, editors, Terrestrial vegetation of California. 3rd edition. University of California Press, Berkeley, CA.

JunaK, S., AND D.H. WiLKen. 1998. Sensitive plant status survey, Naval Auxiliary Landing Field, San Clemente Island, California. Final Report. Santa Barbara Botanic Garden, Santa Barbara, CA.

Kaiser-Bunbury, C.N., A. Traveset, and D.M. Hansen. 2010. Conservation and restoration of plant-animal mutualisms on oceanic islands. Perspectives in Plant Ecology, Evolution and Systematics 12:131-143.

KeEgan, D.R., B.E. CoblentZ, AND C.S. Winchell. 1994. Feral goat eradication on San Clemente Island, California. Wildlife Society Bulletin 22:56-61.

KeEley, J.E. 1991. Seed germination and life history syndromes in the California chaparral. Botanical Review 57:81-116.

Kempton, E.A. 2012. Systematics of Eriogonoideae s.s. (Polygonaceae). Systematic Botany 37:723-737.

Kier, G., H. Kreft, T.M. Lee, W. Jetz, P.L. Ibisch, C. Nowicki, J. Mutke, and W. Barthlott. 2009. A global assessment of endemism and species richness across island and mainland regions. Proceedings of the National Academy of Sciences USA 106: 9322-9327.

Kivelä, M., S. Arnaud-Haond, and J. SaramäKi. 2011. EDENetworks: ecological and evolutionary networks. Computer program and documentation distributed by the authors. http://becs.aalto.fi/edenetworks

Knowlton, J.L., C.J. Donlan, G.W. Roemer, A. Samaniego-Herrera, B.S. Keitt, B. Wood, A. AguirreMunoz, K.R. Faulkner, and B.R. Tershy. 2007. Eradication of non-native mammals and the status of insular mammals on the California Channel Islands, USA, and Pacific Baja California Peninsula Islands, Mexico. Southwestern Naturalist 52:528-540.

Kreft, H., W. Jetz, J. MutKe, G. Kier, and W. BarthLOTT. 2008. Global diversity of island floras from a macroecological perspective. Ecological Letters 11:116-127.

Lauretto, M.S., F. Nakano, S.R. Faria Jr., C.A.B. PEREIRA, AND J.M. STERN. 2009. A straightforward multiallelic significance test for the Hardy-Weinberg equilibrium law. Genetics and Molecular Biology 32:619-625.

LitTLE, R.J. 1981. Adventitious rooting in coastal sage scrub dominants. Madroño 28:96-97.

Manel, S., and R. Holderegger. 2013. Ten years of landscape genetics. Trends in Ecology and Evolution 28:614-621. 
McCune, J.L., AND D.A. KNAPP. 2008. The rediscovery and status of Dissanthelium californicum (Poaceae) on Santa Catalina Island, California. Madroño 55:60-68.

McEachern, A.K., D.M. Thomson, and K.A. Chess. 2009. Climate alters response of an endemic island plant to removal of invasive herbivores. Ecological Applications 19:1574-1584.

McEachern, K., D. Wilken, and K.A. Chess. 1997. Inventory and monitoring of California islands candidate plant taxa. U.S. Geological Survey Open-File Report 00-73.

McGlaughlin, M.E., L. Riley, M. Brandsrud, E. Arcibal, M.K. Helenurm, and K. Helenurm. 2015. How much is enough? Minimum sampling intensity required to capture extant genetic diversity in ex situ seed collections: examples from the endangered plant Sibara filifolia (Brassicaceae). Conservation Genetics 16:253-266.

McGlaughlin, M.E., L. Riley, K. Helenurm, and L.E. WaLlace. 2018. Does Channel Island Acmispon (Fabaceae) form cohesive evolutionary groups? Western North American Naturalist 78:739-757.

McGlaughlin, M.E., L.E. Wallace, G.L. Wheeler, G.E. Bresowar, L. Riley, N.R. Britten, and K. Helenurm. 2014. Do the island biogeography predictions of MacArthur and Wilson hold when examining genetic diversity on the near mainland California Channel Islands? Examples from endemic Acmispon (Fabaceae). Botanical Journal of the Linnean Society 174:289-304.

Meyer, S.E., AND A. Paulsen. 2000. Chilling requirements for seed germination of 10 Utah species of perennial wild buckwheat (Eriogonum Michx. [Polygonaceae]). Native Plants Journal 1:18-24.

MoldenKe, A.R. 1976. California pollination ecology and vegetation types. Phytologia 34:304-361.

Montalvo, A.M. 2004. Eriogonum fasciculatum. Pages 314-318 in J.K. Francis, editor, Wildland shrubs of the United States and its territories: thamnic descriptions: volume 1. General Technical Report IITF-GTR-26. U.S. Department of Agriculture, Forest Service, International Institute of Tropical Forestry, San Juan, PR, and U.S. Department of Agriculture, Forest Service, Rocky Mountain Research Station, Fort Collins, CO.

Moody, A. 2000. Analysis of plant species diversity with respect to island characteristics on the Channel Islands California. Journal of Biogeography 27: 711-723.

Morandin L., R. Long, C. Pease, and C. Kremen. 2011. Hedgerows enhance beneficial insects on farms in California's Central Valley. California Agriculture 65:197-201.

Padgett, P.E., S.N. Kee, and E.B. Allen. 2000. The effects of irrigation on revegetation of semi-arid coastal sage scrub in southern California. Environmental Management 26:427-435.

Peakall, R., and P.E. Smouse. 2012. GenAlEx 6.5: genetic analysis in Excel. Population genetic software for teaching and research-an update. Bioinformatics 28:2537-2539.

Petit, R.J., And A. Hampe. 2006. Some evolutionary consequences of being a tree. Annual Review of Ecology, Evolution and Systematics 37:187-214.

Philbrick, R.N., and J.R. Haller. 1977. The Southern California islands. Pages 893-906 in M.G. Barbour and J. Major, editors, Terrestrial vegetation of California. John Wiley \& Sons, New York, NY.
Pollock, L.J., D.F. Rosauer, A.H. Thornhill, H. Kujala, M.D. Crisp, J.T. Miller, and M.A. McCarthy. 2015. Phylogenetic diversity meets conservation policy: small areas are key to preserving eucalypt lineages. Philosophical Transactions of the Royal Society of London, Series B 370:20140007.

Pritchard, J.K., M. Stephens, and P. Donnelly. 2000. Inference of population structure using multilocus genotype data. Genetics 155:945-959.

RataY, S.E., S.E. Vanderplank, and B.T. Wilder. 2014. Island specialists: shared flora of the Alta and Baja California Pacific Islands. Monographs of the Western North American Naturalist 7:161-220.

Raven, P.H. 1963. A flora of San Clemente Island, California. Aliso 5:289-347.

Raven, P.H. 1967. The floristics of the California Islands. Pages 57-67 in R.N. Philbrick, editor, Proceedings of the Symposium on the Biology of the California Islands. Santa Barbara Botanic Garden, Santa Barbara, CA.

Raymond, M., and F. Rousset. 1995. GENEPOP version 1.2: population genetics software for exact tests and ecumenicism. Journal of Heredity 86:248-249.

RedDing, D.W., And A.Ø. Mooers. 2010. Can systematists help decide the relative worth of bits of biodiversity. Systematist 32:4-8.

Redelings, B.D., S. Kumagai, A. Tatarenkov, L. Wang, A.K. Sakai, S.G. Weller, T.M. Culley, J.C. Avise, AND M.K. Uyenoyama. 2015. A Bayesian approach to inferring rates of selfing and locus-specific mutation. Genetics 201:1171-1188.

Reed, D.H., and R. Frankham. 2003. Correlation between fitness and genetic diversity. Conservation Biology 17:230-237.

ReEs, M. 1996. Evolutionary ecology of seed dormancy and seed size. Philosophical Transactions of the Royal Society of London, Series B 351:1299-1308.

Reusch, T.B., A. Ehlers, A. Hämmerli, and B. Worm. 2005. Ecosystem recovery after climatic extremes enhanced by genotypic diversity. Proceedings of the National Academy of Sciences USA 102:2826-2831.

Rick, T.C., T.S. Sillett, C.K. Ghalambor, C.A. Hofman, K. Ralls, R.S. Anderson, C.L. Boser, T.J. Braje, D.R. Cayan, R.T. Chesser, and P.W. Collins. 2014. Ecological change on California's Channel Islands from the Pleistocene to the Anthropocene. BioScience 64:680-692.

RiLEY, L. 2012. Comparative phylogeography of California Channel Island endemic Eriogonum Polygonaceae. Doctoral dissertaion, University of South Dakota, Vermillion, SD.

Riley, L., and M.E. McGlaughlin. 2016. Endemism in native floras of California's Channel Islands correlated with seasonal patterns of aeolian processes. Botany 94:65-72.

Riley, L., M.E. McGlaughlin, and K. Helenurm. 2010. Genetic diversity following demographic recovery in the insular endemic plant Galium catalinense subspecies acrispum. Conservation Genetics 11: 2015-2025.

Riley, L., M.E. McGlaughlin, and K. Helenurm. 2011. Microsatellite primers for the narrowly endemic shrub Eriogonum giganteum Polygonaceae. American Journal of Botany 98:e352-e355.

Riley, L., M.E. McGlaughlin, and K. Helenurm. 2016. Narrow water barriers prevent multiple colonizations and limit gene flow among California Channel 
Island wild buckwheats (Eriogonum: Polygonaceae). Botanical Journal of the Linnean Society 181: 246-268.

Ross, T.S., S. Boyd, AND S. JUnAK. 1996. Additions to the vascular flora of San Clemente Island, Los Angeles County, California, with notes on clarifications and deletions. Aliso 15:27-40.

Rousset, F. 2008. Genepop'07: a complete reimplementation of the Genepop software for Windows and Linux. Molecular Ecology Resources 8:103-106.

SaatKamp, A., P. Poschlod, and D.L. Venable. 2014. The functional role of soil seed banks in natural communities. Pages 263-295 in R.S. Gallagher, editor, The ecology of regeneration in plant communities. 3rd edition. CPI, United Kingdom.

Scherson, R.A., A.A. Albornoz, A.S. Moreira Muñoz, and R. Urbina Casanova. 2014. Endemicity and evolutionary value: a study of Chilean endemic vascular plant genera. Ecology and Evolution 4:806-816.

Schmidt-Lebuhn, A.N., N.J. Knerr, J.T. Miller, and B.D. Mishler. 2015. Phylogenetic diversity and endemism of Australian daisies (Asteraceae). Journal of Biogeography 42:1114-1122.

Schoenherr, A.A., C.R. Feldmeth, and M.J. Emerson. 2003. Natural history of the islands of California. Taylor \& Francis, USA.

Sgrò, C.M., A.J. Lowe, And A.A. Hoffmann. 2011. Building evolutionary resilience for conserving biodiversity under climate change. Evolutionary Applications 4:326-337.

Srivastava, D.S., M.W. Cadotte, A.A.M. MacDonald, R.G. Marushia, and N. Mirotchnick. 2012. Phylogenetic diversity and the functioning of ecosystems. Ecology Letters 15:637-648.

Takezaki, N., M. Nei, and K. Tamura. 2010. POPTREE2: software for constructing population trees from allele frequency data and computing other population statistics with Windows interface. Molecular Biology and Evolution 27:747-752.

Thorne, R.F. 1969. The California islands. Annals of the Missouri Botanical Garden 56:391-408.

Thornhill, A.H., B.D. Mishler, N.J. Knerr, C.E. GonzÁlez Orozco, C.M. Costion, D.M. Crayn, S.W. Laffan, and J.T. Miller. 2016. Continental scale spatial phylogenetics of Australian angiosperms provides insights into ecology, evolution and conservation. Journal of Biogeography 43:2085-2098.

Tierra Data Inc. 2013. Integrated Natural Resources Management Plan Naval Auxiliary Landing Field San Clemente Island, California.

Traill, L.W., C.J.A. BradshaW, and B.W. Brook. 2007. Minimum viable population size: a meta-analysis of 30 years of published estimates. Biological Conservation 139:159-166.

Tucker, C.M., And M.W. CadotTe. 2013. Unifying measures of biodiversity: understanding when richness and phylogenetic diversity should be congruent. Diversity and Distributions 19:845-854.

Tuljapurkar, S., and P. Wiener. 2000. Escape in time: stay young or age gracefully? Ecological Modelling 133:143-159.
Van Oosterhout, C., W. Hutchinson, D.P.M. Wills, AND P. SHIPLEY. 2004. Micro-checker: software for identifying and correcting genotyping errors in microsatellite data. Molecular Ecology Notes 4: 535-538.

Vellend, M., G. Lajoie, A. Bourret, C. Múrria, S.W. Kembel, and D. Garant. 2014. Drawing ecological inferences from coincident patterns of populationand community-level biodiversity. Molecular Ecology 23:2890-2901.

Volkmann, L., I. Martyn, V. Moulton, A. Spillner, and A.Ø. Mooens. 2014. Prioritizing populations for conservation using phylogenetic networks. PLOS ONE 9:e88945.

WaLl, M. 2008. Seed collections of Rancho Santa Ana Botanic Garden: seed storage guidelines. Rancho Santa Ana Botanic Gardens, Claremont, CA.

Wallace, L.E., M.S. Furches, and K. Helenurm. 2006. Polymorphic microsatellite loci in Lithophragma maximum (Saxifragaceae), an endemic plant of San Clemente Island. Molecular Ecology Notes 6: 459-461.

Wallace, L.E., and K. Helenurm. 2009. Has herbivory negatively impacted genetic variability in the flora of the California Channel Islands? Insights from Crossosoma californicum (Crossosomataceae). International Journal of Plant Sciences 170:311-322.

Watson, S. 1885. Contributions to American botany. Proceedings of the American Academy of Arts and Sciences 20:324-378.

Weigelt, P., W.D. Kissling, Y. Kisel, S.A. Fritz, D.N. Karger, M. Kessler, S. Lehtonen, J.C. Svenning, AND H. KREFT. 2015. Global patterns and drivers of phylogenetic structure in island floras. Scientific Reports 5:12213.

Whittaker, R.J., K.A. Triantis, and R.J. Ladle. 2008. A general dynamic theory of oceanic island biogeography. Journal of Biogeography 35:977-994.

Winter, M., V. Devictor, and O. Schweiger. 2013. Phylogenetic diversity and nature conservation: where are we? Trends in Ecology and Evolution 28:199-204.

WyLIE, D.D. 2012. Vegetation change on San Clemente Island following the removal of feral herbivores. Master's thesis, San Diego State, San Diego, CA.

Yelenik, S.G., AND J.M. Levine. 2010a. Processes limiting native shrub recovery in exotic grasslands after non-native herbivore removal. Restoration Ecology $18: 418-425$.

YeleniK, S.G., AND J.M. LeVIne. 2010b. Native shrub reestablishment in exotic annual grasslands: do ecosystem processes recover? Ecological Applications 20:716-727.

YeleniK, S.G., AND J.M. Levine. 2011. The role of plantsoil feedbacks in driving native-species recovery. Ecology 92:66-74.

Received 28 February 2017

Revised 12 February 2018

Accepted 14 March 2018

Published online 13 December 2018 